\title{
Pentingnya Pengembangan SDM
}

\author{
Nun Tufa*
}

\begin{abstract}
Training and development is very important because tuntuntan from the world of a very complex organization, thus forcing an organization to conduct training and development so that employees are able to work in accordance with the expectations of the organization. Although many new employees are university graduates but in fact many of the employees are still confused with what they should do. In addition, capacity equalization is also a part of the objectives of human resource training and development.

Human Resource Development is a form of effort to develop the quality of human resource capability through various process of planning method of education, training, and management of personnel or employees to achieve a satisfactory result.
\end{abstract}

Keywords; training, development, human resources

\section{A. Pendahuluan}

Sumber daya manusia adalah aset terpenting dalam sebuah perusahaan, hal ini karena perannya yang sentral. Oleh karena itu perlu ada perhatian lebih terhadap SDM agar semua elemen sistem yang terdapat dalam sebuah perusahaan berjalan dengan baik.

Sumber daya manusia sendiri adalah seluruh kemampuan atau potensi penduduk yang berada di dalam suatu wilayah tertentu beserta karakteristik atau ciri demografis, sosial maupun ekonominya yang dapat dimanfaatkan untuk keperluan pembangunan. Jadi membahas sumber daya manusia berarti membahas penduduk dengan segala potensi atau kemampuannya. Potensi manusia menyangkut dua aspek yaitu aspek kuantitas dan kualitas (M.M. Papayungan, 1995: 110). Potensi manusia yang nantinya ditunjukkan dalam aspek yang salah satunya adalah kualitas, hanya dapat dicapai dengan adanya pengembangan SDM. Hal tersebut diperlukan karena sumber daya manusia merupakan factor yang paling mempengaruhi kehidupan. Kemampuan manusia untuk mempengaruhi alamnya menunjukkan bahwa posisi SDM sangat sentral adanya. Oleh karena itu, sumber daya manusia yang ada hendaklah dikembangkan sedemikian rupa guna mencapai kesejahteraan. Pengembangan SDM ini amat diperlukan karena memiliki aspek yang penting bagi peningkatan produktivitas SDM dan juga memiliki tujuan-tujuan terntentu yang pastinya harus dicapai demi kemajuan pembangunan suatu bangsa.

Pelatihan dan pengembangan SDM menjadi suatu keniscayaan bagi organisasi karena penempatan karyawan secara langsung dalam pekerjaan tidak menjamin mereka berhasil. Karyawan baru sering merasa tidak pasti tentang peranan dan tanggung jawab mereka. Permintaan pekerjaan dan kapasitas karyawan haruslah seimbang melalui program orientasi dan pelatihan, keduanya sangat dibutuhkan. Hal ini dapat diasumsikan bahwa pelatihan dan pengembangan sangat penting bagi tenaga kerja untuk lebih menguasai dan lebih baik terhadap pekerjaan yang dijabat atau akan dijabatnya (Tubagus, 2015:82).

\footnotetext{
* Dosen Tetap Fak. Febi Institut IImu keislaman Zainul hasan genggong Kraksaan Probolinggo
} 
Pelatihan serta pengembangan SDM yang tepat sasaran akan memberikan efek yang baik terhadap karyawan. Karyawan dapat mengembangkan diri dan mampu memahami seluk-beluk pelaksanaan pekerjaan lebih mendalam, dapat memahami perkembangan perusahaan, memahami sasaran yang akan dicapai perusahaan, mengerti akan perlunya kerjasama dalam melaksanakan pekerjaan, dapat dengan mudah memahami Informasi yang disampaikan perusahaan, dapat memahami setiap kesulitan-kesulitan yang dihadapi perusahaan, mampu melakukan hubungan-hubungan dengan lingkungan, mampu memahami kebijaksanaan dan peraturan yang berlaku dalam perusahaan, mampu memahami sistem dan prosedur yang digunakan dalam pelaksanaan tugas perusahaan, mampu memahami dan menerapkan perilaku yang mendukung dan dituntut perusahaan. Sehingga seluruh tugas dari pimpinan atau manajemen akan terasa lebih ringan.

\section{B. Pembahasan}

\section{Pengertian Sumber Daya Manusia (SDM)}

Sumber daya manusia adalah individu produktif yang bekerja sebagai penggerak suatu organisasi, baik itu di dalam institusi maupun perusahaan yang memiliki fungsi sebagai aset sehingga harus dilatih dan dikembangkan kemampuannya. Pengertian sumber daya manusia makro secara umum terdiri dari dua yaitu SDM makro yaitu jumlah penduduk dalam usia produktif yang ada di sebuah wilayah, dan SDM mikro dalam arti sempit yaitu individu yang bekerja pada sebuah institusi atau perusahaan.

Menurut Mathis dan Jackson (2006), sumber daya manusia merupakan suatu rancangan berbagai sistem formal dalam perusahaan maupun organisasi yang berfungsi untuk menjaga agar penggunaan bakat dan minat manusia dapat digunakan untuk mencapai tujuan organisasi atau perusahaan tersebut secara efektif dan efisien.

Sonny Sumarsono (2003) mengartikan bahwa sumber daya manusia mempuyai beberapa pengertian yaitu sumber daya manusia adalah usaha kerja yang bermanfaat bagi keberlangsungan produksi. Sedangkan makna yang kedua, sumber daya manusia merupakan kelompok manusia yang terdiri dari manusia yang memiliki kemampuan untuk memberikan jasa.

Menurut Straub dan Attner (1985) yang dikutip dalam Gaol (2014;44) mendefinisikan manusia sebagai sumber daya yang paling penting dari sebuah organisasi. Manusia memberikan bakat, keahlian, pengetahuan, dan pengalaman untuk mencapai tujuan-tujuan organisasi

Sumber Daya Manusia (SDM) merupakan suatu hal yang sangat penting dan harus dimiliki dalam upaya mencapai tujuan organisasi atau perusahaan. Sumber daya manusia merupakan elemen utama organisasi dibandingkan dengan elemen sumber daya yang lain seperti modal, teknologi, karena manusia itu sendiri yang mengendalikan faktor yang lain.

Dari pengertian di atas dapat disimpulkan bahwa SDM adalah aset terpenting dalam suatu perusahaan sehingga SDM perlu untuk dikembangkan sejalan dengan perubahan tegnologi yang sangat cepat.

\section{Pengertian Pengembangan SDM}

Pengembangan SDM adalah wujud usaha mengembangkan kualitas dari kemampuan sumber daya manusia melalui berbagai proses metode perencanaan 
pendidikan, pelatihan, dan pengelolaan tenaga atau pegawai untuk mencapai suatu hasil yang memuaskan.

Pengembangan SDM dapat didefinisikan sebagai seperangkat aktivitas yang sistematis dan terencana yang dirancang dalam memfasilitasi para pegawainya dengan kecakapan yang dibutuhkan untuk memenuhi tuntutan pekerjaan, baik pada saat ini maupun masa yang akan datang (Harrish and Desimone, 1998:2).

Pengembangan SDM berkaitan dengan tersedianya kesempatan dan pengembangan belajar, membuat program-program training yang meliputi perencanaan, penyelenggaraan, dan evaluasi atas program-program tersebut (Armstrong, 1997:504)

Menurut Tubagus (2015:83)Pengembangan (development) diartikan sebagai penyiapan individu untuk memikul tangung jawab yang berbeda atau yang lebih tinggi dalam perusahaan, organisasi, lembaga, atau instansi pendidikan.

Dari beberapa pengertian di atas, dapat disimpulkan bahwa pengembangan SDM adalah segala bentuk aktivitas yang bertujuan untuk memfasilitasi karyawan agar memiliki pengetahuan, keahlian, dan sikap yang diperlukan untuk menangani jobdis saat ini atau yang akan datang. Aktivitas yang dimaksud, tidak hanya pada aspek pendidikan dan pelatihan saja, akan tetapi menyangkut aspek karier dan pengembangan organisasi. Dengan kata lain, pengembangan SDM berkaitan erat dengan upaya meningkatkan pengetahuan, kemampuan, dan sikap anggota organisasi serta penyediaan jalur karier yang didukung oleh fleksibilitas organisasi dalam memcapai tujuan organisasi.

\section{Tujuan Pengembangan SDM}

Setiap organisasi pasti akan berupaya agar tujuannya tercapai dengan efektif dan efisien. Efektifitas dan efisiensi organisasi sangat bergantung pada baik buruknya pengembangan SDM atau anggota organisasi itu sendiri. Ini berarti bahwa SDM yang ada dalam organisasi tersebut secara proporsional harus diberikan latihan serta pendidikan yang terbaik.

Pada umumnya penegembangan lebih bersifat filosofis dan teoritis, dibandingkan dengan kegiatan pelatihan. Serta pengembangan lebih diarahkan untuk golongan manajer, sedangkan program pelatihan ditujukan untuk golongan non manajer. Meskipun terdapat perbedaan antara keduanya, namun perlu disadari bahwa baik latihan maupun pengembangan keduanya fokus pada peningkatan keterampilan ataupun kemampuan.

Dari uraian di atas jelas, bahwa tujuan organisasi atau perusahaan akan dapat tercapai dengan baik apabila karyawan dapat menjalankan tugasnya dengan efektif dan efisien. Sehingga untuk itu usaha pengembangan sumber daya manusia dalam organisasi/perusahaan yang bersangkutan sangatlah diperlukan. Dengan demikian dapat ditarik kesimpulan, bahwa tujuan pengembangan sumber daya manusia termaksud adalah untuk memperbaiki efektivitas dan efisiensi kerja mereka dalam melaksanakan dan mencapai sasaran program-program kerja yang telah ditetapkan. Perbaikan efektivitas dan efisiensi karyawan dapat dicapai dengan meningkatkan: pengetahuan, keterampilan dan sikap karyawan terhadap tugas-tugasnya.

Tujuan pengembangan karyawan adalah untuk memperbaiki efektivitas kerja karyawan dalam mencapai hasil-hasil kerja yang telah ditetapkan. Perbaikan efektivitas kerja dapat dilakukan dengan cara memperbaiki pengetahuan karyawan, keterampilan 
karyawan maupun sikap karyawan itu sendiri terhadap tugas-tugasnya (Heidjrachman dan Husnan, 2004:74).

Menurut Tubagus (2015:85) Tujuan diselenggarakan pelatihan dan pengembangandiarahkan untuk membekali ,meningkatkan, dan mengembangkan kompetensi kerja guna meningkatkan kemampuan, produktivitas dan kesejahteraan (). Adapun tujuannya sebagai berikut.

a. Meningkatkan mutu dan produktivitas kerja

b. Meningkatkan ketepatan dalam perencanaan SDM

c. Meningkatkan semangat kerja

d. Menjaga kesehatan dan keselamatan kerja

e. Menunjang pertumbuhan pribadi (personal growth)

Pengembangan karyawan bertujuan dan bermanfaat bagi perusahaan, karyawan, konsumen, atau masyarakat yang mengkonsumsi barang/jasa yang dihasilkan perusahaan. Menurut (Tohardi, 2008 : 70) tujuan pengembangan adalah:

a. Produktivitas. Dengan pengembangan, produktivitas kerja karyawan akan meningkat, kualitas dan kuantitas produksi akan semakin baik, karena technical skill, human skilldan managerial skill karyawan akan semakin baik.

b. Efisiensi. Pengembangan karyawan untuk meningkatkan efisiensi sumber daya manusia, waktu, bahan baku dan mengurangi ausnya mesin-mesin. Pemborosan berkurang, biaya produksi relatif kecil sehingga daya saing perusahaan semakin kecil.

c. Kerusakan. Pengembangan karyawan bertujuan untuk mengurangi kerusakan barang, produksi dan mesin-mesin karena karyawan semakin ahli dan terampil dalam melaksanakan pekerjaannya.

d. Kecelakaan. Pengembangan bertujuan untuk mengurangi tingkat kecelakaan karyawan, sehingga jumlah biaya pengobatan yang keluarkan perusahaan berkurang.

e. Pelayanan. Pengembangan bertujuan untuk meningkatkan pelayanan yang lebih baik dari karyawan kepada nasabah perusahaan, karena pemberian pelayanan yang lebih baik merupakan daya penarik yang sangat penting bagi rekananrekanan perusahaan bersangkutan.

f. Moral. Dengan pengembangan, moral karyawan akan lebih baik karena keahlian dan keterampilannya sesuai dengan pekerjaannya sehingga merek antusias menyelesaikan pekerjaannya dengan baik.

g. Karier. Dengan pengembangan, kesempatan untuk meningkatkan karier karyawan semakin besar, karena keahlian, keterampilan dan prestasi kerjanya lebih baik, promosi ilmiah biasanya didasarkan kepada keahlian dan prestasi kerja seseorang.

h. Konseptual. Dengan pengembangan, manajer akan semakin cakap dan cepat dalam mengambil keputusan yang lebih baik, karena technical skill, human skill dan managerial skill nya lebih baik.

i. Kepemimpinan. Dengan pengembangan, kepemimpinan seorang manajer akan lebih baik, human relationsnya lebih luas, motivasi lebih terarah sehingga pembinaan kerja sama vertikal dan horizontal semakin harmonis.

j. Balas Jasa. Dengan pengembangan, balas jasa (gaji, upah, intensif dan benefit) karyawan akan meningkat karena prestasi kerja mereka semakin besar.

k. Konsumen. Pengembangan karyawan akan memberikan manfaat yang lebih baik bagi masyarakat konsumen karena mereka akan memperoleh barang atau pelayanan yang lebih bermutu. 


\section{Pentingnya Pengembangan SDM}

Pengembangan SDM sangat diperlukan untuk dilakukan secara berkesenambungan dan terencana. Agar proses pengembangan dapat terlaksana dengan baik maka perlu ditetapkan suatu planing yang matang terkait pengembangan SDM. Progam pengembangan SDM hendaknya disusun secara cermat dan didasarkan kepada metode-metode ilmiah serta berpedoman pada keterampilan yang dibutuhkan perusahaan saat ini maupun masa depan. Pengembangan haruslah bertujuan untuk meningkatkan kemampuan teknis, teoritis, konseptual serta moral sumber daya manusia supaya prestasi kerjanya baik dan mencapai hasil yang optimal.

Pengembangan SDM semakin penting manfaatnya karena tuntutan jabatan dari suatu pekerjaan, apalagi dengan kemajuan tegnologi yang begitu cepat serta semakin ketatnya persaingan antar perusahaan sejenis. Setiap sumber daya manusia yang ada di dalam suatu perusahaan (dunia kerja) dituntut agar bekerja efektif, efisien kualitas dan kuantitas pekerjaannya baik sehingga daya saing perusahaan semakin besar. Pengembangan ini dilakukan untuk tujuan nonkarier maupun karier bagi sumber daya manusia melalui latihan dan pendidikan.

Pemimpin atau manajer suatu perusahaan semakin sadar tentang pentingnya pengembangan SDM. Apalagi ketika SDM yang baru memasuki dunia kerja pada faktanya hanya memiliki kemampuan secara teorotis yang mereka dapati di bangku kuliah ataupun dari jenjang pendidikan yang mereka tempuh. Jadi, pengembangan perlu dilakukan, karena untuk melatih, meningkatkan serta menyetarakan kemampuannya secara nyata untuk dapat menyelesaikan pekerjaannya dengan efektif dan efesien. Pengembangan SDM ini sangatlah penting meskipun membutuhkan dana yang besar dalam prosesnya, akan tetapi dngan biaya yang besar tersebut hal ini merupakan investasi jangka panjang bagi perusahaan. Karena dengan hal ini, maka sumber daya manusia yang ada akan terampil dan cakap, sehingga ketika mereka menyelesaikan pekerjaannya (melakukan) maka mereka akan bekerja lebih efektif, efisien, mengurangi pemborosan bahan baku dan peralatan maupun perlengkapan lainnya akan lebih awet dalam pemeliharaannya. Hasil kerjanya pun akan lebih baik yang akan berimbas pula pada meningkatnya daya saing perusahaan. Dengan daya saing yang besar ini, maka akan dapat dipastikan bahwa perusahaan tersebut nantinya akan memiliki peluang yang lebih baik agar mampu memperoleh laba yang maksimal maupun tujuan yang telah ditetapkan pada awal akan tercapai secara keseluruhan. Imbasnya bagi sumber daya manusia yang ada maka akan memdapatkan penghargaan berupa gaji yang maksimal, sehingga dapat digunakan untuk sarana memperbaiki diri dan juga penyemangat dalam bekerja.

Pengembangan SDM sendiri juga dapat dibedakan menjadi dua, yakni pengembangan SDM secara makro dan secara mikro. Pengembangan sumber daya secara makro penting sekali dalam rangka mencapai tujuan pembangunan secara efektif. Pengembangan sumber daya secara makro ini bertumpu pada pengertian bahwa pengembangan SDM yang terarah dan terencana disertai pengelolaan yang baik akan dapat menghemat sumber daya alam yang ada, atau setidaknya pengelolaan dan pemakaian sumber daya alam dapat secara tepat guna. Karena SDM yang telah dikembangkan sedmikian rupa, akan memiliki skill yang cukup untuk memanfaatkan hasil alam secara berkelanjutan.

Yang kedua adalah pengembangan SDM secara mikro. Pengembangan SDM secara mikro ini lebih menekankan pada pengoptimalan hasil kerja yang maksimal dalam suatu perusahaan. 
Baik secara makro maupun mikro, pengembangan SDM jelaslah menuju pada sasaran yakni peningkatan kualitas sumber daya manusia yang nantinya akan bermuara pada pembangunan bangsa. Dalam pembangunan suatu bangsa memerlukan aspek pokok yang disebut dengan sumber daya (resources) baik SDA atau Natural resources maupun SDM atau human resources. Kedua sumber daya ini sangat penting dalam menentukan keberhasilan suatu pembangunan. Namun untuk mendukung suatu pembangunan, SDM adalah yang terpenting, karena jika sebuah negara memiliki suatu SDM yang terampil dan berkualitas maka ia akan mampu mengelola SDA yang jumlahnya terbatas.

Untuk Negara-negara berkembang, dimana terdapat "Labour Surplus Economy" artinya modal pembangunan tak dapat dituangkan hanya pada tersedianya atau kemungkinan tersedianya dana investasi. Pembangunan tersebut akan terlalu mahal dan juga akan mengalami hambatan apabila sesuatu waktu sumber investasi menjadi terbatas, baik yang berasal dari pemerintah maupun dari masyarakat. Selain itu jumlah SDM yang besar hendaknya dijadikan sebagai keunggulan karena jumlah penduduk yang besar apabila dapat dikembangkan sebagai tenaga kerja yang efektif akan merupakan modal pembangunan yang besar yang sangat menguntungkan bagi usaha - usaha disegala bidang.

\section{Teknik pengembangan SDM}

Program-program pelatihan dan pengembangan dirancang untuk meningkatkan prestasi kerja, mengurangi absensidan perputaran, serta memperbaiki kepuasan kerja. Terdapat dua katagori pokok program pelatihan dan pengembangan manajemen (decenzo \& robbins:1999:230), yaitu (1) metode praktis (on the job training), (2) teknik-teknik presentasi informasi dan metode-metode simulasi (of the job training).

Masing-masing katagori mempunyai sasaran pengajaran sikap konsep atau pengetahuan serta keterampilan utama yang berbeda. Dalam pemilihan tekniktertentu untuk digunakan pada program pelatihan dan pengembangan, ada beberapa trade offs. Ini berarti tidak satu teknik yang selalu baik. Metode tergantung pada sejauh mana suatu teknik memenuhi faktor-faktor berikut:

a. Efektifitas biaya.

b. Isi program yang dikehendaki

c. Kelayakan fasilitas-fasilitas

d. Preferensi dan kemampuan peserta

e. Preferensi dan kemampuan instruktur atau pelatih

f. Prinsip-prinsip belajar

Teknik-teknik on the job merupakan metode latihan yang paling banyak digunakan. Karyawan dilatih tentang pekerjaan baru dengan supervisi langsungdari seorang pelatihyang berpengalaman (biasanya karyawan lain). Berbagai macam teknik ini yang bisa digunakan dalam praktik adalah sebagai berikut:

1. Rotasi jabatan

m. Latihan instruksi pekerjaan

n. Magang

o. Coacing

p. Penugasan sementara

Teknik-teknik of the job, dengan pendekatan ini karyawan peserta latihan menerima representasi tiruan (artcial) suatu aspek organisasi dan diminta untuk 
menanggapinya sperti dalam keadaan sebenarnya. Adapun tujuan utama teknik presentasi (penyajian) informasi adalah untuk mengajarkan berbagai sikap, konsep atau keterampilan kepada para peserta.

Implementasi program pelatihan dan pengembangan berfungsi sebagai proses transformasi. Para tenaga kerja (karyawan) yang tidak terlatih diubah menjadi karyawan-karyawan yang berkemampuan dan berkualitas dalam bekerja, sehingga dapa diberikan tanggung jawab lebih besar (Tubagus, 2015:86-87).

\section{Kendala Dalam Pelatihan Dan Pengembangan}

Seringkali kelemahan pelatih bisa menyebabkan sebuah program pelatihan mengalami kegagalan. Satu pemahaman terhadap masalah potensial ini harus dijelaskan selama pelatihan kepada trainer. Simamora (2006:282) mengidentifikasikan kelemahan pelatihan dan pengembnagn sebagai berikut :

a. Pelatihan dan pengembangan dianggap sebagai obat untuk semua penyakit organisasional.

b. Partisipan tidak cukup termotivasi untuk memusatkan perhatian dan komitmen mereka.

c. Sebuah teknik dianggap dapat diterapkan disemua kelompok, dalam semua situasi, dengan keberhasilan yang sama.

d. Kinerja partisipan tidak dievaluasi begitu karyawan telah kembali ke pekerjaanya.

e. Informasi biaya-manfaat untuk mengevaluasi program pelatihan tidak dikumpulkan.

f. Ketidakadaan atau kurangnya kurangnya manajemen.

g. Peran utama atasan tidak diakui.

h. Pelatihan bakal tidak pernah cukup kuat untuk menghasilkan perbaikan kinerjayang dapat diverifikasi.

i. Sedikit atau tidak ada persiapan untuk tindak lanjut.

\section{Evaluasi Terhadap Pengembangan SDM}

Evaluasi pelatihan memiliki fungsi sebagai pengendali proses dan hasil program pelatihan sehingga akan dapat dijamin suatu program pelatihan yang sistematis, efektif dan efisien. Evaluasi pelatihan merupakan suatu proses untuk mengumpulkan data dan informasi yang diperlukan dalam program pelatihan. Evaluasi pelatihan lebih difokuskan pada peninjauan kembali proses pelatihan dan menilai hasil pelatihan serta dampak pelatihan yang dikaitkan dengan kinerja SDM. Evaluasi merupakan bagian yang sangat penting dari program pelatihan, mengingat telah banyak menghabiskan waktu, energi, serta biaya untuk pelaksanaannya. Agar pelatihan tidak sia-sia, suatu langkah evaluasi dan tindak lanjut dilakukan secara teratur. Evaluasi suatu program pelatihan diperlukan untuk mengetahui seberapa jauh peningkatan pengetahuan, keterampilan dan sikap staf terjadi dan seberapa besar penerapannya dalam memberikan arti atau pengaruh pada dirinya, kelompok dan organisasinya.

\section{Tujuan Dari Evaluasi Pelatihan Pengembangan SDM}


Adapun tujuan dari program evaluasi pelatihan Pengembangan SDM antara lain, sebagai berikut:

1. Menemukan dan menganalisa informasi mengenai pencapaian tujuan dalam jangka pendek dan jangka panjang.

2. Mengetahui pengaruh program pelatihan terhadap kinerja hasil implementasinya.

3. Mengetahui dengan cepat kemungkinan utnuk perbaikan dan sinkronisasi program pelatihan sesuai dengan perkembangan situasi dalam organisasi.

4. Mengetahui reaksi peserta terhadap sebagian atau keseluruhan program pelatihan

5. Mengetahui hasil pembelajaran peserta

6. Mengantisipasi tindakan tertentu ketika diperlukan untuk mengambil langkahlangkah perbaikan

7. Mengetahui hasil pelaksanaan pelatihan dan pengaruhnya terhadap kinerja serta masalah-masalahnya.

8. Mengetahui opini pemimpin dan bawahan peserta mengenai hasil pelatihan

9. Mengetahui hubungan hasil pelatihan serta dampaknya bagi organisasi di tempat peserta bekerja.

\section{Evaluasi Program - Program Pelatihan Pengembangan SDM}

Evaluasi setelah pelatihan pada tingkat perilaku dalam pekerjaan sangat penting, karena belum tentu pengetahuan dan pengalaman pembelajaran yang diperoleh dapat diterapkan dalam pekerjaan, tetapi perilaku yang baik dalam pekerjaan merupakan gabungan dari pengetahuan, keterampilan dan sikap.

Pelatihan mestilah di evaluasi dengan sistematis mendokumentasikan hasil-hasil pelatihan dari segi bagaimana sesungguhnya peserta pelatihan berperilaku kembali pada pekerjaan mereka dan relevansinya perilaku peserta pada tujuan-tujuan perusahaan. Dalam menilai manfaat atau kegunaan program pelatihan, perusahaan mencoba menjawab empat pertanyaan (Simamora, 1997):

1. Apakah terjadi perubahan?

2. Apakah perubahan disebabkan oleh pelatihan?

3. Apakah perubahan secara positif berkaitan dengan pencapaian tujuan-tujuan organisasional

4. Apakah perubahan yang serupa terjadi pada partisipan yang baru dalam program pelatihan yang sama?

Evaluasi membutuhkan adanya penilaian terhadap dampak program pelatihan pada perilaku sikap dalam jangka pendek maupun jangka panjang. Adapun pengukuran efektifitas penilaian meliputi penilaian (Simamora, 1997):

10. Reaksi-reaksi yaitu bagaimana perasaan partisipan terhadap program.

11. Belajar yaitu pengetahuan, keahlian, dan sikap-sikap yang diperoleh sebagai hasil dari pelatihan.

12. Perilaku yaitu perubahan - perubahan yang terjadi pada pekerjaan sebagai akibat dari pelatihan. 
13. Hasil-hasil yaitu dampak pelatihan pada keseluruhan efektifitas organisasi atau pencapaian pada tujuan - tujuan organisasional.

Pengukuran reaksi dan belajar yang bersangkut paut dengan hasil-hasil program pelatihan saja disebut dengan kriteria internal. Pengukuran perilaku dan hasil-hasil yang mengindikasikan dampak pelatihan pada lingkungan pekerjaan disebut sebagai kriteria eksternal yaitu dukungan dari pihak manajemen memberi kesempatan peserta pelatihan mempraktikkan apa yang telah mereka peroleh dari pelatihan.

Adanya pengukuran efektivitas pelatihan yang telah dilaksanakan dapat disimpulkan bahwa evaluasi pelatihan baik mengenai program maupun instruktur/pelatih dapat menjadi umpan balik untuk pelatihan selanjutnya demikian pula dengan pembelajaran mereka apakah mereka mempelajari prinsip - prinsip, ketrampilan, dan fakta-fakta yang seharusnya mereka pelajari. Selanjutnya dapat untuk mengetahui apakah perilaku peserta berubah karena program pelatihan atau bukan. Terakhir dengan melihat hasil dari pelatihan apakah sesuai dengan tujuan pelatihan yang ditetapkan.

\section{E. Penutup}

Pelatihan dan pengembangan sangat penting karena tuntuntan dari dunia organisasi yang sangat kompleks, sehingga memaksa sebuah organisasi melakukan pelatihan serta pengembangan agar para karyawan mampu bekerja sesuai dengan harapan organisasi. Meskipun banyak karyawan baru yang lulusan universitas namun faktanya banyak dari para karyawan masih bingung dengan apa yang harus mereka kerjakan. Selain itu penyetaraan kemampuan juga menjadi bagian dari tujuan pelatihan dan pengembangan SDM.

Agar pelatihan dapat berjalan dengan baik perlu adanya konsep yang matang serta pelatih yang ahli sehingga perusahaan tidak membuang dana dan waktu yang sia-sia. Selain itu adanya evaluasi yang mendalam juga perlu dilakukan untuk memastikan bahwa pelatihan dan pengembangan berjalan dengan baik.

dengan memperhatikan beberapa hal tersebut maka besar kemungkinan pelatihan dan pengembangan akan memberikan dampak yang baik yang diharapkan oleh organisasi sehingga dana dan waktu yang dikorbankan tidak sia-sia. 


\section{Daftar pustaka}

Achmad, tubagus, 2015. Konsep-konsep Dasar Manajemen Personalia Masa Kini (Bandung:Refika Aditama)

Ahmad Tohardi, 2007, Pemahaman Praktis Manajemen Sumber Daya Manusia (Pontianak: Mandar Maju),

DeSimone,R.L,\& Harris, d.m. 1998. Human Resources Development. Second edition. (Orlando; The Dryden Press)

DeCenzo, D. A. \& Robbins, S. P. (1999). Human Resource Management. (6th Ed.) (John Wiley and Sons, Inc., USA)

Gaol, J.L. 2014. A to Z Human Capital. (Jakarta: PT. Grasindo Anggota Ikapi)

Heidjrachman dan S. Husnan. 2004. Manajemen Sumber Daya Manusia (BPFE.

Yogyakarta)

Kotler, Philip., dan Gary Armstrong., 1997, Dasar-Dasar Pemasaran, Edisi ketujuh, Jilid 1, dialihbahasakan oleh Alexander Sindoro (Jakarta: Prenhallindo)

Mathis, R.L. \& J.H. Jackson. 2006. Human Resource Management: Manajemen Sumber Daya Manusia. Terjemahan Dian Angelia( Jakarta: Salemba Empat)

M.M Papayungan.1995.Pengembangan dan Peningkatan Mutu Sumber Daya Manusia Menuju Masyarakat Industrial Pancasila (Bandung: Mizan)

Sumarsono, Sonny. 2003. Ekonomi Manajemen Sumber Daya Manusia dan Ketenagakerjaan (Yogyakarta : Graha Ilmu)

Simamora. 2006. Manajemen Sumber Daya Manusia. Cetakan Kedua. (Bogor :Ghalia Indonesia) 